\title{
Proto-Oncogene Ets-1 and the Kidney
}

\author{
M.S. Razzaque ${ }^{a, b}$ T. Naito ${ }^{a, c}$ T. Taguchi ${ }^{a}$ \\ a2nd Department of Pathology, Nagasaki University School of Medicine, Nagasaki, Japan; \\ bDepartment of Oral Medicine and Diagnostic Sciences, Harvard School of Dental Medicine, Boston, Mass., USA; \\ 'Department of Medicine, Kidney Center, Tokyo Woman's Medical College, Tokyo, Japan
}

\section{Introduction}

Most forms of advanced glomerular diseases, if not all, are characterized by abnormal turnover of extracellular matrix (ECM) proteins in glomeruli, resulting in structural alterations of glomerular basement membrane and mesangial matrix, usually leading to proteinuria. It is, therefore, important to elucidate the regulatory mechanisms of ECM metabolism in glomerular diseases. Various types of collagens, laminin, fibronectin, and sulfated proteoglycans are the normal components of glomerular matrix [15]. In vivo and in vitro studies have shown that these matrix components are produced by mesangial and visceral epithelial cells $[6,7]$. It has also been demonstrated that in glomerular diseases, phenotypically altered activated renal cells are mainly responsible for the increased production of these matrix components as well as diseasespecific matrix components that are not expressed in the normal kidney [8-11]. Several lines of evidence now suggest that an imbalance between synthesis and degradation of these matrix components is closely associated with accumulation of ECM and subsequent progression of renal diseases [12]. Matrix metalloproteinases (MMPs) and tissue inhibitors of metalloproteinases (TIMPs) have been reported to play an important role in ECM remodeling in various renal diseases $[13,14]$.

Recent studies have also shown that the proto-oncogene Ets-1 plays a role in the transcriptional regulation of matrix proteinases such as MMP-3 and u-PA [15-19]. We summarize herein the existing information about possible roles of Ets-1 in matrix remodeling as well as other functions in renal diseases.

\section{Ets-1 Proto-Oncogene}

The $c$-ets- 1 gene has been identified as the cellular progenitor of viral oncogene v-ets which is associated with $v-m y b$ in the genome of the avian leukemia retrovirus E26 [20]. The $c$-ets- 1 gene product Ets- 1 is composed of 450 amino acids and contains DNA-binding ETS domain, transactivation domain, and pointed domain. The ETS domain binds to the ETS-binding motif GGAA/T in the cis-acting element of target genes and cooperates with the c-Fos/c-Jun complex at AP-1 site to activate the expression of certain promoters [21]. This motif has been found in the promoter region of numerous genes including MMP-1, MMP-3, MMP-9, u-PA, and TIMP-1 [15-18, 22].

The expression of Ets-1 proto-oncogene has been detected in various cells, and the role of ets-1 gene expressed in mesodermal lineage cells such as fibroblasts and endothelial cells has drawn a wide attention in the fields of embryogenesis and angiogenesis [23-26]. Ets-1 has been shown to be transiently expressed in the endothelial cells during vascular development in the embryo and during

\section{KARGER \\ Fax +41613061234 \\ E-Mail karger@karger.ch \\ www.karger.com

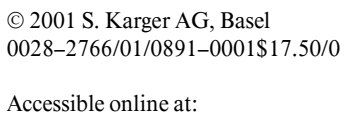

M.S. Razzaque, MBBS, PhD

Department of Oral Medicine and Diagnostic Sciences, Harvard School of Dental Medicine 188 Longwood Avenue

Boston, MA 02115 (USA)

E-Mail mrazzaque@hms.harvard.edu 
angiogenesis in the adult $[24,27,28]$. Elimination of the expression of Ets-1 resulted in inhibition of cell migration and invasion and angiogenic activity of endothelial cells [29]. Ets-1 proto-oncogene plays an important role in $\mathrm{T}$ cell activation [30]. High levels of ets-1 gene expression have been demonstrated in T lymphocytes and that such expression is essential for the maintenance of the normal pool of resting $\mathrm{T}$ cells $[31,32]$ and that the Ets-1-binding site is contained in $\mathrm{T}$ cell receptor gene enhancer and CD4 gene core promoter [33, 34]. Moreover, recent studies have also shown that Ets-1 protein exhibits multifunctional activities in the transcriptional regulation of numerous genes including MMP-3 and u-PA [15-18].

\section{Ets-1 and MMPs}

It has been demonstrated that Ets- 1 protein interacts with the promoter genes coding for proteinases including MMP-1, MMP-3, and u-PA and could enhance the promoter activity of these genes.

MMPs are generally classified into five categories based on their properties: collagenases (MMPs 1, 8, 13, and 18), gelatinases (MMPs 2 and 9), stromelysins (MMPs 3 and 10), membrane-type MMPs (MMPs 1417), and others (MMPs 7, 11, 12, and 19) [35]; these zincdependent proteases play a vital role in the turnover of ECM components including collagens, elastin, laminin, proteoglycans, fibronectin, and other glycoproteins.

The progression of renal diseases due to structural remodeling has been shown to be associated not only with excessive synthesis of matrix proteins [36-38], but also with an imbalance between synthesis and degradation of MMPs and TIMPs in various types of glomerular diseases $[13,14]$. Earlier studies have shown that glomerular resident cells express and secrete several types of MMPs, including gelatinase A (MMP-2), stromelysin-1 (MMP-3), and gelatinase B (MMP-9) in both animal and human kidneys [39-43]. Altered expression of MMP-3 and TIMP-1 has been detected in renal biopsy sections in various renal diseases including IgA nephropathy $[39,40]$. In the passive Heymann nephritis model, McMillan et al. [41] demonstrated a marked increase in MMP-9, commonly known as type I collagenase synthesis within glomerular epithelial cells. Moreover, in vitro studies have shown the expression of a variety of MMPs by cultured mesangial and/or glomerular epithelial cells [42, 43]. It is generally accepted that matrix-degrading proteinases play an important role in various renal diseases, and it seems that Ets-1 protein regulates the transcriptional activity of sev- eral proteinases; therefore, to elucidate the role of Ets-1 in human and experimental renal diseases ought to widen our knowledge about the pathomechanism of disease process.

\section{Ets-1 and the Kidney}

Numerous studies have shown that ets- 1 gene is essential for the normal development of mammalian kidneys and the maintenance of glomerular integrity and that Ets-1 protein may act as an upstream regulator for the expression of FREAC-4, a winged helix transcriptional factor detected during nephrogenesis [44, 45]. Ets-1 has been shown to be expressed during early kidney development in the tubular structures of mesonephros day E10.5 p.c. [46]. Moreover, the ets-1 knockout mouse kidney showed various glomerular abnormalities including sclerosis, atrophy, and markedly fewer and immature glomeruli [44]. These results denote an essential role for Ets-1 for a normal structural development of the kidney.

The renin-angiotensin system plays an important role in the regulation of blood pressure and electrolyte metabolism in the kidney. Renin, which is synthesized by renal juxtaglomerular cells, catalyzes the conversion of angiotensinogen to angiotensin I. Ets-1 has been shown to bind the human renin gene promoter, and potential exists for a role of Ets-1 in the renin-angiotensin system, possibly by regulating the expression of renin in the kidney [47].

Angiogenic factors like basic fibroblast growth factor, vascular endothelial growth factor, and epidermal growth factor have been shown to induce the expression of Ets-1 in human endothelial cells. Moreover, Ets-1 plays an important role in angiogenesis by regulating the expression of u-PA and MMP-1 and migration of endothelial cells $[19,23,29]$. As a pathogenic role of basic fibroblast growth factor, vascular endothelial growth factor, and epidermal growth factor has been reported in various renal diseases [48], it will be interesting to explore whether these growth factor induced renal injuries are partly regulated by Ets-1 proto-oncogene.

Recently, we found a coordinated upregulation of MMP-3 and Ets-1 in experimentally induced crescentic glomerulonephritis. The expression pattern and cellular distribution of MMP-3 and Ets-1 protein were similar, and MMP-3-positive renal cells often expressed Ets-1 protein in the diseased kidney, revealing a close association between Ets-1 and MMP-3 expression [49]. From the results of this in vivo study, it has been concluded that upregulation of the expression of MMP-3 possibly by the 
transcriptional activation of Ets-1 might participate in the matrix remodeling in renal diseases. Further studies using human renal tissue are necessary to determine the possible role of Ets-1 proto-oncogene in various renal diseases.

\section{Conclusions}

Although comprehensive studies are required to clarify the precise role of Ets-1 in renal injury, however, existing information seems to indicate its broad biological functions in the kidney, ranging from embryonic development to disease process. Over the past several years, remarkable progress has been made in understanding the molecular mechanisms of tissue remodeling in normal and diseased kidneys [1, 8, 12, 13, 43, 50]. However, very little is known about possible involvement of Ets-1 and other transcriptional factors in the initiation of disease processes. An advance in molecular biology techniques has allowed us to identify most of the factors and even predict their roles (to some extent) in routine biopsy sections. Applying all these molecular biological techniques, identifying regulating factors like Ets-1, those that might actively participate in initiating the immuno-inflammatory cascade in various renal diseases and establishing an effective therapeutic strategy by targeting those early factors to treat and/or control the progression of disease process will be an enormous clinical challenge.

\section{Acknowledgments}

We thank the staffs of the Second Department of Pathology, Nagasaki University School of Medicine, for their excellent technical support.

\section{References}

1 Razzaque MS, Kumatori A, Harada T, Taguchi $\mathrm{T}$ : Coexpression of collagens and collagenbinding heat shock protein 47 in human diabetic nephropathy and IgA nephropathy. Nephron 1998;80:434-443.

2 Pihlajaniemi T: Molecular properties of the glomerular basement membrane; in Tryggvason K (ed): Molecular Pathology and Genetics of Alport syndrome. Contrib Nephrol, Basel, Karger, 1995, vol 117, pp 46-79.

3 Razzaque MS, Shimokawa I, Nazneen A, Liu D, Naito T, Higami Y, Taguchi T: Life-long dietary restriction modulates the expression of collagens and collagen-binding heat shock protein 47 in aged Fischer 344 rat kidney. Histochem J 1999;31:123-132.

4 Martin GR, Timpl R, Kuhn K: Basement membrane proteins: Molecular structure and function. Adv Protein Chem 1988;39:1-50.

5 Razzaque MS, Taguchi T: Collagen-binding heat shock protein (HSP) 47 expression in antithymocyte serum (ATS)-induced glomerulonephritis. J Pathol 1997;183:24-29.

6 Ishimura E, Sterzel RB, Budde K, Kashgarian $\mathrm{M}$ : Formation of extracellular matrix by cultured rat mesangial cells. Am J Pathol 1989; 134:843-855

7 Razzaque MS, Koji T, Harada T, Taguchi T: Localization in situ of type VI collagen protein and its mRNA in mesangial proliferative glomerulonephritis using renal biopsy sections. Histochem Cell Biol 1999;111:1-6.

8 Norman JT, Fine LG: Progressive renal disease: Fibroblasts, extracellular matrix, and integrins. Exp Nephrol, 1999;7:167-177.
9 Razzaque MS, Koji T, Harada T, Taguchi T: Identification of type VI collagen synthesizing cells in human diabetic glomerulosclerosis using renal biopsy sections. Anal Cell Pathol 1997; 15:175-181.

10 Yoshioka K, Tohda M, Takemura T, Akano N, Matsubara K, Ooshima A, Maki S: Distribution of type I collagen in human kidney diseases in comparison with type III collagen. J Pathol 1990;162:141-148.

11 Razzaque MS, Shimokawa I, Nazneen A, Higami Y, Taguchi T: Age-related nephropathy in the Fischer 344 rat is associated with overexpression of collagens and collagen-binding heat shock protein 47. Cell Tissue Res 1998;293: 471-478.

12 Eddy AA: Molecular basis of renal fibrosis. Pediatr Nephrol 2000;15:290-301.

13 Davies M, Martin J, Thomas GJ, Lovett DH: Proteinase and glomerular matrix turnover. Kidney Int 1992;41:671-678.

14 Johnson RJ: The glomerular response to injury: Progression or resolution? Kidney Int 1994;45: 1769-1782.

15 Nerlov C, Cesare DD, Pergosa F, Caracciolo A, Blasi F, Johnsen M, Verde P: A regulatory element that mediates cooperation between a PEA3-AP-1 element and an AP-1 site is required for phorbol ester induction of urokinase enhancer activity in HepG2 hepatoma cells. EMBO J 1992;11:4573-4582.

16 Gutman A, Wasylyk B: The collagenase gene promoter contains a TPA and oncogene-responsive unit encompassing the PEA3 and AP1 binding sites. EMBO J 1990;9:2241-2246.
17 Gum R, Lengyel E, Juarez J, Chen JH, Sato H, Seiki M, Boid D: Stimulation of 92-kDa gelatinase $\mathrm{B}$ promoter activity by ras is mitogen-activated protein kinase kinase 1-independent and requires multiple transcription factor binding sites including closely spaced PEA3/ets and AP-1 sequences. J Biol Chem 1996;271:1067210680.

18 Wasylyk C, Gutman A, Nicholson R, Wasylyk $\mathrm{B}$ : The c-Ets oncoprotein activates the stromelysin promotor through the same elements as several non-nuclear oncoproteins. EMBO J 1991;10:1127-1134.

19 Sato Y, Kanno S, Oda N, Abe M, Ito M, Shitara K, Shibuya M: Properties of two VEGF receptors, Flt-1 and KDR, in signal transduction. Ann NY Acad Sci 2000;902:201-205.

20 Nunn MF, Seeburg PH, Moscovici C, Duesberg $\mathrm{PH}$ : Tripartite structure of the avian erythroblastosis virus E26 transforming gene. Nature 1983;306:391-395.

21 Wasylyk B, Wasylyk C, Flores P, Begue A, Leprince D, Stehelin D: The c-ets proto-oncogenes encode transcription factors that cooperate with c-Fos and c-Jun for transcriptional activation. Nature 1990;346:191-193.

22 Logan SK, Garabedian MJ, Campbell CE, Werb Z: Synergistic transcriptional activation of the tissue inhibitor of metalloproteinase- 1 promoter via functional interaction of AP-1 and ets- 1 transcriptional factors. J Biol Chem 1996;271:774-782.

23 Iwasaki C, Tanaka K, Abe M, Sato Y: Ets-1 regulates angiogenesis by inducing the expression of urokinase-type plasminogen activator and matrix metalloproteinase- 1 and the migration of vascular endothelial cells. J Cell Physiol 1996;169:522-531. 
24 Kola I, Brookes S, Green AR, Garber R, Tymms M, Papas TS, Seth A: The Ets1 transcription factor is widely expressed during murine embryo development and is associated with mesodermal cells involved in morphogenetic processes such as organ formation. Proc Natl Acad Sci USA 1993;90:7588-7592.

25 Naito S, Shimizu S, Maeda S, Wang J, Paul R, Fagin JA: Ets-1 is an early response gene activated by ET-1 and PDGF-BB in vascular smooth muscle cells. Am J Physiol 1998;274: C472-C480.

26 Hultgardh-Nilsson A, Cercek B, Wang J, Naito S, Lovdahl C, Sharifi B, Forrester JS, Fagin JA: Regulated expression of the Ets-1 transcriptional factor in vascular smooth muscle cells in vivo and in vitro. Circ Res 1996;78:589-595.

27 Vandenbunder B, Pardanaud L, Jaffredo T, Mirabel MA, Stehelin D: Complementary patterns of expression of c-ets $1, \mathrm{c}-\mathrm{myb}$ and c-myc in the blood-forming system of the chick embryo. Development, 1989;107:265-274.

28 Wernert N, Raes MB, Lassalle P, Dehouck MP, Gosselin B, Vandenbunder B, Stehelin D: cets1 proto-oncogene is a transcription factor expressed in endothelial cells during tumor vascularization and other forms of angiogenesis in humans. Am J Pathol 1992;140:119-127.

29 Sato Y: Transcription factor ETS-1 as a molecular target for angiogenesis inhibition. Hum Cell 1998;11:207-214.

30 Bhat NK, Thompson CB, Lindsten T, June $\mathrm{CH}$, Fujiwara S, Koizumi S, Fisher RJ, Papas TS: Reciprocal expression of human ETS1 and ETS2 genes during T-cell activation: Regulatory role for the protooncogene ETS1. Proc Natl Acad Sci USA 1990;87:3723-3727.

31 Bories JC, Willerford DM, Grevin D, Davidson L, Camus A, Martin P, Stehelin D, Alt FW: Increased T-cell apoptosis and terminal B-cell differentiation induced by inactivation of the Ets-1 proto-oncogene. Nature 1995;377:635638.

32 Muthusamy N, Barton K, Leiden JM: Defective activation and survival of $\mathrm{T}$ cells lacking the Ets-1 transcription factor. Nature 1995 , 377:639-642.
33 Salmon P, Giovane A, Wasylyk B, Klatzmann D: Characterization of the human CD4 gene promoter: Transcription from the CD4 gene core promoter is tissue-specific and is activated by Ets proteins. Proc Natl Acad Sci USA 1993; 90:7739-7743.

34 Ho IC, Bhat NK, Gottschalk LR, Lindsten T, Thompson CB, Papas TS, Leiden JM: Sequence-specific binding of human Ets-1 to the $\mathrm{T}$ cell receptor alpha gene enhancer. Science 1990;250:814-818.

35 Nagase H: Activation mechanism of matrix metalloproteinases. Biol Chem 1997;378:151160.

36 Razzaque MS, Koji T, Taguchi T, Harada T, Nakane PK: In situ localization of type III and type IV collagen-expressing cells in human diabetic nephropathy. J Pathol 1994;174:131138.

37 Couser WG, Johnson RJ: Mechanisms of progressive renal disease in glomerulonephritis. Am J Kidney Dis 1994;23:193-198.

38 Razzaque MS, Koji T, Kawano H, Harada T, Nakane PK, Taguchi T: Glomerular expression of type III and type IV collagens in benign nephrosclerosis: Immunohistochemical and in situ hybridization study. Pathol Res Pract 1994;190:493-499.

39 Miyazaki M, Koji T, Furusu A, Abe K, Ozono Y, Harada T, Naka R, Suzuki D, Yagame M, Endoh M, Nomoto Y, Hara K, Nakane PK, Sakai H: In situ hybridization studies of stromelysin and tissue inhibitor of metalloproteinase 1 in IgA nephropathy. Nephrology 1995;1: 119-127.

40 Akiyama K, Shikata K, Sugimoto H, Matsuda M, Shikata Y, Fujimoto N, Obata K, Matsui H, Makino $\mathrm{H}$ : Changes in serum concentrations of matrix metalloproteinases, tissue inhibitors of metalloproteinases and type IV collagen in patients with various types of glomerulonephritis. Res Commun Mol Pathol Pharmacol 1997;95: $115-128$.
41 McMillan JI, Riordan JW, Couser WG, Pollock AS, Lovett DH: Characterization of a glomerular epithelial cell metalloproteinase as matrix metalloproteinase- 9 with enhanced expression in a model of membranous nephropathy. J Clin Invest 1996;97:1094-1101.

42 Marti HP, McNeil L, Davies M, Martin J, Lovett DH: Homology cloning of rat $72-\mathrm{kDa}$ type IV collagenase: Cytokine and second-messenger inducibility in glomerular mesangial cells. Biochem J 1993;291:441-446.

43 Steinmann-Niggli K, Lukes M, Marti HP: Rat mesangial cells and matrix metalloproteinase inhibitor: Inhibition of 72-kD type IV collagenase (MMP-2) and of cell proliferation. J Am Soc Nephrol 1997;8:395-405.

44 Chernavvsky DR, Fernandez LG, Barton K, Muthusamy N, Leiden JM, Gomez RA: Expression and function of the ETS-1 gene in the developing kidney (abstract). J Am Soc Nephrol 1998;9:360.

45 Cederberg A, Hulander M, Carlsson P, Enerback $\mathrm{S}$ : The kidney-expressed winged helix transcription factor FREAC-4 is regulated by ets-1: A possible role in kidney development. J Biol Chem 1999;274:165-169.

46 Queva C, Leprince D, Stehelin D, Vandenbunder B: p54c-ets- 1 and p68c-ets-1, the two transcription factors encoded by the c-ets-1 locus, are differentially expressed during the development of the chick embryo. Oncogene 1993;8: 2511-2520.

47 Konoshita T, Germain S, Philippe J, Corvol P, Pinet F: Evidence that renal and chorionic tissues contain similar nuclear binding proteins that recognize the human renin promoter. Kidney Int 1996;50:1515-1524.

48 Hyink DP, Abrahamson DR: Origin of the glomerular vasculature in the developing kidney. Semin Nephrol 1995;15:300-314.

49 Naito T, Razzaque MS, Nazneen A, Liu D, Nihei H, Koji T, Taguchi T: Renal expression of the ets- 1 proto-oncogene during progression of rat crescentic glomerulonephritis. J Am Soc Nephrol 2000; 11:2243-2255.

50 Razzaque MS, Ahsan N, Taguchi T: Heat shock protein 47 in renal scarring. Nephron 2000;86:339-341. 